KATHY MEZEI teaches Canadian and Quebec Literature at Simon Fraser University and is interested in the translation of the two literatures.

\title{
The Question of Gender in Translation: Examples from Denise Boucher and Anne Hébert: A Corollary to Evelyne Voldeng's Trans lata latus (Tessera, No. 1)
}

KATHY MEZEI

No man or woman but has felt, during a lifetime, the subtle barriers which sexual identity interposes in communication. At the heart of intimacy, there above all perhaps, differences of linguistic reflex intervene... Under stress of hatred, of boredom, of sudden panic, great gaps open. It is as if a man and woman then heard each other for the first time and knew, with sickening conviction, that they share no common language... It is not as translators that women novelists, and poets excel, but as declaimers of their own, long-stifled tongue.

George Steiner, "Understanding Translation"'

But how well in fact is women's "long-stifled tongue" translated from one language to another, from one text to another? As the translator begins the act of translation, certain factors inevitably influence this act of creation and interpretation: the place and time of the source language and the target language, the literary and translating community surrounding the translator, whether the translator is a writer, whether the translator is a critic or comparatist (in the sense of understanding the source language's culture) ${ }^{2}$, and the gender of the translator. I would like to pursue Steiner's observations about differences in communication between men and women as they engage in the activity of language ("inside or between languages, human

1. G. Steiner, After Babel: Aspects of Language and Translation, Oxford: Oxford University Press, 1975), pp. 41, 44, 45.

2. A good example of a translator not understanding the culture of the source language occurs in Hannah Josephson's (a New Yorker unfamiliar with Quebec) translation of Gabrielle Roy's Bonheur 
communication equals translation" $)^{3}$ by focussing on gender in translation.

In her paper, "Trans lata latus," to which this discussion is corollary, Evelyne Voldeng comments:

Si la traduction est fonction du traducteur, à l'époque actuelle où plusieurs femmes-écrivains revendiquent la spécificité d'une écriture féminine il peut être intéressant de comparer les traductions par des féministes et par des hommes de textes poétiques féministes ou d'inspiration féministe. Une telle comparaison permet de faire certaines observations générales. Les traductions faites par des femmes... montrent une recherche beaucoup plus systématique du mot concret en particulier au niveau biophysiologique. ${ }^{4}$

As feminist literary critics unveil the mask of gender from translations of women writers by male translators, they begin to query whether the source text's images and ideas have been sensitively and accurately rendered. I think, for example, of Alan Brown's occasionally jarring translation of Denise Boucher's controversial play, Les fées ont soif, (The Fairies are Thirsty, Vancouver, 1975), jarring because insensitive to the feminité of the text, to certain nuances. The play presents three characters, the Virgin Mary, the whore and the housewife who gradually demolish myths about their feminine roles. When Marie, the housewife, remarks "J'ai eu deux enfants et c'est comme ma chair n'avait jamais été traversée," this is translated too literally by Brown as "I had two kids and I feel as if I'd never been traversed". (I would have said: "I had two kids and I feel as if I'd never been penetrated"). Brown or the publisher also leaves out the significant following sentence "Pourquoi une mère n'aurait-elle joui?" ("Why couldn't a mother have felt sexual pleasure?") Madelaine, the whore's speculation, "Disons que / $\mathrm{j}$ 'aurais jamais mes règles rouges" is translated as "Let's say / my rags are never red" (I would have said: "Let's say / I would never get my bloody period"). These literal renditions do not capture Boucher's ironic comments on the feminine condition, or her colloquial and earthy tone.

d'occasion (The Tin Flute) in which she does not recreate a recognizable Montréal.

3. Steiner, p. 47.

4. This paper appears in Tessera, I, Room of One's Own, 8, No. 4(1985) pp. 82, 84. 
Of the at least eight well-known translators of Anne Hébert's poetry, only one has been a woman - the poet, Gwladys Downes. ${ }^{5}$ Yet the persona, images, perspective and experience of Hébert's poems are undeniably feminine. The persona often resembles the frail yet lugubrious girlish figure portrayed in "La Fille maigre": "Je suis une fille maigre / Et j'ai de beaux os" (Poèmes, Paris, 1960, p. 33). Neither F.R. Scott's translation "I am a lean girl / And I have beautiful bones," ("The Lean Girl", The Poetry of French Canada in Translation, Toronto, 1970, p. 132) or Alan Brown's "I am a thin girl' With fine bones," (Poems, Toronto, 1975, p. 29) quite captures the desperate fleshlessness of the persona, though Scott, a fine translator of Hébert's poetry creates a sharper, more poetic rendition. Occasionally, however, he is too casual about the gender of the speaker in Hébert's poems. When for example, he translates the opening lines of "La Chambre fermée", there is no clear indication of gender in contrast to the French where the "e" on "conduite" signals that the "me" is feminine:

Qui donc m'a conduite ici?

Il y a certainement quelqu'un

Qui a soufflé sur mes pas.

(Poèmes, p. 39)

as

Who then brought me here?

There was certainly someone

Who prompted my steps.

("The Closed Room," The Poetry of French Canada, p. 134)

Many of Hébert's images alternate between an illusory frailty and surreal violence, suggesting a young woman's ambivalence in leaving behind her often macabre childhood world to descend into the shock of adulthood. As Patricia Smart explains:

Les traits spécifiques de la féminité tels que définis par Clément, Hélène Cixous et d'autres - monde renversé porteur d'un nouvel ordre, subversion instaurée par le regard d'une enfant sauvage, affirmation de la puissance, d'Eros contre le pouvoir repressif du Logos - sont en effet

5. The translators are F. R. Scott, G. R. Roy, Peter Miller, Alan Brown, Alfred Poulin, Jr., Fred Cogswell, Ralph Gustafson, and Gwladys Downes. 
les clés de voûte de l'univers hébertien... ces trois receuils de poésie tracent le cheminement solitaire d'une femme déchue qui réclame avec passion "le fer et le feu de son héritage" (Poèmes, 92)... la possibilité d'un renouvellement vient de la femme qui possède en elle le secret des origines et du désir. La femme apparaît toutefois dans les poèmes d'Hébert comme reléguée au domaine du songe,...6

By precise attention to Hébert's images and rhythms in her translation of "Une Petite Morte", Gwladys Downes creates a poem that is at the same time more concrete and eloquent than did Alan Brown.

Hébert's poem opens:

Une petite morte s'est couchée en travers de la porte

Nous l'avons trouvée au matin, abattue sur notre seuil

Comme un arbre de fougère plein de gel.

Nous n'osons plus sortir depuis qu'elle est là

C'est une enfant blanche dans ses jupes mousseuses

D'où rayonne une étrange nuit laiteuse.

(Poèmes, p. 47)

Downes' version is:

A little dead girl is lying across our doorstep

We found her in the morning, curled on the sill

Like bracken touched by frost.

Now that she is there

We do not dare go out

This pale child in her frothy skirts, shedding

A strange milky darkness.

(The Poetry of French Canada, p. 40)

6.Patricia Smart, "La poésie d'Anne Hébert: une perspective féminine," University of Ottawa Quarterly, 50, 1 (January-March, 1980). 
Brown's version is:

A small dead girl

lay down across the doorsill

We found her there on the morning, struck down on our threshold

Like a fern crushed by frost.

Since she came to us we dare not pass the door

She is a child white in her foaming skirts

From which a strange milky darkness rises.

(Poems, p. 29)

Downes has entered the poem, its experience, its images, while Brown stands outside, awkwardly. Downes' "curled on the sill" is more rhythmic and evocative than Brown's "struck down on our threshold"; "this pale child in her frothy skirts" is a line of poetry, while "she is a child white in her foaming skirts" is too literal a rendering. Although Downes has such a finely tuned ear to Hébert's nuances, she has unfortunately translated only three of her poems.?

In the famous "Le Tombeau des rois," Poèmes, pp. 59-61, an interesting problem of gender in translation arises. In this poem, a young girl descends into the tomb of kings, tremulously encounters the entombed kings, the grip of death and the deadly past, and after submitting to "la main sèche qui cherche le coeur pour le rompre" emerges to face the dawn "ses prunelles crevées" (with "blinded eyes"). In the second, third and fourth stanzas Anne Hébert writes:

Je descends

Vers les tombeaux des rois

Étonnée

A peine née

Quel fil d'Ariane me mène

Au long des dédales sourds?

L'écho des pas s'y mange à mesure.

(En quel songe

Cette enfant fut-elle liée par la cheville

Pareille a une esclave fascinée?)

7. "A Little Dead Girl," "The Planting of Hands," "A Touch of Despair," in The Poetry of French Canada in Translation, (Montreal: Harvest House) pp. 140-142; also in Gwladys Downes, Out of the Violent Dark (Victoria, 1978). 
Originally Frank Scott translated these last three lines as:

(In what dream

Was this child tied by the ankle

Like a fascinated slave?)

His translation ignored the fact that the child was a girl, indicated in French by "étonnée", "née", "cette enfant" and "une esclave fascinée". Both the image of the child, and the child as female are important to the tone and theme of the poem in that the horror and the magnificence of the tomb of the dead kings (deadly, patriarchal, and powerful) into which she descends contrasts with her own fragility. It is important for the reader to realize that Ariadne's thread leads a young; girl, image or kin of Ariadne, helpless and passive, not an adventurous manly Theseus, through the sepulchral labyrinth, and that consequently the young girl is "raped" by the heavy hand of death, the patriarchal past: "Ils me couchent et me boivent; / Sept fois, je connais l'étau des os." It was Anne Hébert who, in Dialogue sur la traduction, which contains the correspondence between Hébert and Scott over the translation of "Le Tombeau des rois" and three versions of the translation, pointed out the error in gender. After trying "girl-child", Scott finally solved the problem with "her ankle" instead of "the ankle".

However, the response of several other translators to this problem indicates insensitivity to the gender of the speaker, to the experience undergone in the poem, to the significance of sexual difference, and to differences in the manifestation of gender in English and French. Two other translators - Alan Brown and Alfred Poulin, Jr. never acknowledge the child as female, although both could have had access to Scott's translation and to the Dialogue. Peter Miller, who did read the Dialogue, also used "her ankle". This example from "Le Tombeau des rois" illustrates Voldeng's contention that translators need to pay attention to "la spécifité d'une écriture féminine", that gender is a significant factor affecting translation. Women's "longstifled tongue" should not be further stifled or betrayed by insensitive translations.

8. Anne Hébert et Frank Scott, Dialogue sur la traduction (Montréal: HMH, 1970), p. 37.

9. In French, gender is indicated by the definite (le, la) or indefinite (un, une) article, demonstrative pronouns (ce, cette), and by ending of adjectives and past participles ("une esclave fascinée," "qui donc m'a conduite ici") as well as, of course, by nouns and pronouns, whereas in English gender has fewer expressions - primarily by nouns (the girl), pronouns (she), and possessive adjectives (her book). 